\title{
Longitudinal Changes in Growth Hormone Response to Growth Hormone-Releasing Hormone in Neonatal Rhesus Monkeys
}

\author{
MARK D. WHEELER AND DENNIS M. STYNE
}

Department of Pediatrics, University of California, Davis, School of Medicine, Davis, Callfornia 95616

\begin{abstract}
To determine whether differential response to growth hormone-releasing hormone (GHRH) could cause the developmental changes seen in growth hormone (GH) secretion, we administered $10 \mu \mathrm{g} / \mathrm{kg}$ GHRH (1-44 $\mathrm{NH}_{2}$ ) to a group of four unanesthetized, fasted, rhesus monkeys via acutely placed venous catheters at 1, 7, 14, and $28 \mathrm{~d}$ postnatal age. Serum GH was assayed by hGH RIA in sera collected at $-60,-30,0,15,30,45,60$, and 90 min relative to the GHRH bolus. Serum cortisol was measured by ELISA in the 0-, 30-, and 60-min samples. Differences between age groups were analyzed by repeated measures analysis of variance and paired $t$ tests. Mean basal GH levels were higher at $1 \mathrm{~d}(9.4 \pm 1.2 \mu \mathrm{g} / \mathrm{L}$, mean \pm SEM) than at $7(5.5 \pm 0.4), 14(5.6 \pm 0.5)$, and $28 \mathrm{~d}$ $(5.3 \pm 0.5)$ of age. There were no other significant differences in mean basal GH values between the age groups. Mean post-GHRH GH concentrations decreased significantly with each age after $1 \mathrm{~d}(22.6 \pm 1.6): 7 \mathrm{~d}(16.4 \pm$ $1.3) ; 14 \mathrm{~d}(11.3 \pm 1.0)$; and $28 \mathrm{~d}(7.9 \pm 0.9)$. Similarly, mean $\delta$-GH values decreased with each increase in age from $1 \mathrm{~d}(15.0 \pm 1.9): 7 \mathrm{~d}(10.9 \pm 1.6) ; 14 \mathrm{~d}(5.9 \pm 1.1)$ and $28 \mathrm{~d}(2.7 \pm 0.8)$. Serum cortisol was not correlated with serum $\mathrm{GH}$ at any age. Our study demonstrates decreasing basal GH concentration and GH responses to GHRH with advancing age from 1 to $28 \mathrm{~d}$ in the rhesus monkey. The spontaneous decline in GH concentration observed during the first few days of life may reflect a decrease in pituitary gland response to GHRH stimulation. (Pediatr Res 28: 15-18, 1990)
\end{abstract}

\section{Abbreviations}

GH, growth hormone

GHRH, growth hormone-releasing hormone

SRIH, somatostatin.

ANOVA, analysis of variance

The changing pattern of $\mathrm{GH}$ secretion during ontogenic development has been demonstrated in a variety of mammalian species (1). The changes in plasma $\mathrm{GH}$ in the infant rhesus monkey are similar to those in the infant human, where elevated GH concentrations at birth are followed by a rapid decline shortly thereafter (2). The etiology of this developmental pattern is not known. Relative resistance to the inhibitory effects of SRIH have been implicated in rats $(3-5)$ and sheep $(6,7)$. Differences in

Received January 1. 1990; accepted March 1, 1990.

Correspondence and reprint requests: Dennis M. Styne, M.D. Chairman, Department of Pediatrics. University of California, Davis, MSIA, Room I I34, Davis, California 95616.

Supported in part by NIH Giant I R01 DK 35842-01 AI and Califormia Primate Research Center Grant PHS-RRO169.
GHRH secretion and/or somatotroph responsiveness may also be responsible for these changes in rats (8) and sheep (6). Elevated serum GH concentration in the neonatal rat may also be influenced by maturational changes in mechanisms of pituitary $\mathrm{GH}$ release (9). Evidence from studies of $\mathrm{GH}$ secretion in anencephalic human infants suggests that hypothalamic stimulation, presumably by GHRH, may be responsible for the increased $\mathrm{GH}$ concentrations seen in human neonates (10). Administration of GHRH to human neonates has shown either a greater GH response than seen in older individuals $(11,12)$ or no response at all (13). A cross-sectional developmental study in rhesus monkeys demonstrated a decreased GH response to GHRH by 1 wk of age (2).

No detailed study of the dynamic GH response to GHRH during the neonatal period has been reported in primates. We studied the GH response to exogenous GHRH in a group of neonatal rhesus monkeys followed longitudinally to determine whether differential response to GHRH could be a cause of the developmental changes in $\mathrm{GH}$ secretion.

\section{MATERIALS AND METHODS}

Animals. Rhesus monkeys (Macaca mulatta) were studied longitudinally at the California Primate Research Center. A total of 15 studies were performed on four thesus monkeys (two male, two female) from 1 to $28 \mathrm{~d}$ of age. The study was approved by primate and animal use committees and animals were maintained according to $\mathrm{NIH}$ guidelines for humane animal care.

Experimental procedure. Four animals were studied at 1,14 , and $28 \mathrm{~d}$ of age and three of the four at $7 \mathrm{~d}$. On the day of study, monkeys were temporarily removed from their mothers, fasted for $2 \mathrm{~h}$, and then restrained on a padded board. Intravenous catheters were acutely placed in a saphenous vein and normal saline with $4 \mathrm{IU} / \mathrm{mL}$ of heparin was infused at $5 \mathrm{~mL} / \mathrm{h}$ throughout the procedure. The animals were allowed to stabilize for $1 \mathrm{~h}$ after placement of the i.v. catheter before blood sample collection was begun.

GHRH (1-44 $\mathrm{NH}_{2}$ ) was graciously supplied by Dr, Ling of the Salk Institute for Biological Studies (Lot 129-133) (14). The peptide was weighed before use and dissolved in sterile saline and bacteriostatic water immediately before use. After $120 \mathrm{~min}$ had passed from the time of insertion of the i.v. catheter and institution of the heparin-saline infusion, the GHRH solution was administered in a dose of $10 \mu \mathrm{g} / \mathrm{kg}$ body wt by i.v. bolus through the saphenous catheter. Blood samples of $0.4-0.7 \mathrm{~mL}$ were collected through the i.v. line at $-60,-30,0,15,30,45$, 60 , and 90 min relative to the GHRH bolus. Samples were centrifuged immediately and the serum removed and stored at $-20^{\circ} \mathrm{C}$ until assayed. Red blood cells from each sample were resuspended in sterile heparinized saline and reinfused into the animal immediately after removal of the serum.

Assays. Monkey GH is similar to human GH (15) and is characteristically analyzed in hGH assays $(16,17)$; thus, monkey 
serum samples were analyzed in triplicate for concentration of GH using a human RIA system with standards (GH Lot AFP 4793-B) and antibody (Lot 97720133) supplied by the National Hormone and Pituitary Program (Baltimore, MD). All samples from a given experiment were run in the same assay. Intraassay and interassay coefficients of variation were 6.0 and $9.2 \%$, respectively. The minimal detectable serum concentration was 0.1 $\mu \mathrm{g} / \mathrm{L}$.

Serum cortisol was measured in sera from 0,30 , and $60 \mathrm{~min}$ after GHRH by ELISA after extraction of monkey sera in ethanol using antisera developed in Dr. G. Stabenfeldt's laboratory (AB/ Z) (18). All cortisol measurements were performed in duplicate in the same assay; intraassay variation was about $7 \%$, and $50 \%$ displacement was $20 \mathrm{pg}$. Assay sensitivity was $0.25 \mathrm{pg} /$ well.

Statistics. Data are expressed as mean \pm SEM. Mean basal $\mathrm{GH}$ results were analyzed by comparing all $\mathrm{GH}$ values before GHRH administration ( $-60,-30$, and $0 \mathrm{~min}$ ) for each animal at a given age. GH response to GHRH infusion was analyzed using mean postinfusion $G H$ concentration $(15,30,45,60$, and 90 min) of each animal at a given age and mean $\delta-G H$ was determined by taking the differences between the $\mathrm{GH}$ value at time 0 and each of the post-GHRH GH concentrations of each animal at a given age. Differences in mean basal, mean postGHRH, and mean $\delta-G H$ levels between the various age groups were analyzed with repeated measures ANOVA and paired $t$ tests. Differences in cortisol levels were also analyzed with ANOVA and paired $t$ tests. Age group comparisons were also made between peak $\mathrm{GH}$, time $0 \mathrm{GH}$, and $\delta$-peak $\mathrm{GH}$ (difference between peak and time $0 \mathrm{GH}$ concentrations), and area under the curve post-GHRH with and without baseline subtraction using repeated measures ANOVA and Scheffe test for multiple comparisons (19). Differences with a probability of less than 0.05 (two-tailed) were considered significant. Linear regression was used to analyze for any correlation between $\mathrm{GH}$ and cortisol levels at each age.

\section{RESULTS}

Mean basal $\mathrm{GH}$ levels were higher at $1 \mathrm{~d}(9.4 \pm 1.2 \mu \mathrm{g} / \mathrm{L})$ than at $7 \mathrm{~d}(5.5 \pm 0.4, p=0.021), 14 \mathrm{~d}(5.6 \pm 0.5, p=0.014)$, and 28 $\mathrm{d}(5.3 \pm 0.5, p=0.002)$ of age. There were no other significant differences in mean basal $\mathrm{GH}$ values among the age groups (Fig. 1).

Mean post-GHRH GH concentrations showed a significant decrease with each advance in age from $1 \mathrm{~d}(22.6 \pm 1.6): 7 \mathrm{~d}$ (16.4 \pm I.3), $14 \mathrm{~d}(11.3 \pm 1.0)$, and $28 \mathrm{~d}(7.9 \pm 0.9)$ (Fig. 1). Similarly, mean $\delta$-GH values decreased with each increase in age from $1 \mathrm{~d}(15.0 \pm 1.9): 7 \mathrm{~d}(10.9 \pm 1.6), 14 \mathrm{~d}(5.9 \pm 1.1)$, and 28 d $(2.7 \pm 0.8)$ (Fig. 1).

A similar pattern exists among the age groups for peak $\mathrm{GH}$, \&peak $\mathrm{GH}$, time $0 \mathrm{GH}$, and area post-GHRH with and without baseline subtraction. However, due to the smaller number of data points used in these analyses, only the 1-d versus 14-d and 1-d versus 28-d peak GH and area post-GHRH and 1-d versus 28-d $\delta$-peak $\mathrm{GH}$ are statistically significant (Table 1).

Previous studies in our lab have demonstrated no change in serum GH concentrations in rhesus monkeys age 1 to $31 \mathrm{~d}$ after i.v. administration of saline, normal rabbit serum, or sheep $\gamma$ globulin (20). Thus, the rises seen in GH after GHRH in these monkeys is a specific effect of the hypothalamic peptide.

Serum cortisol values were elevated above levels found in human neonates and adults (21) in all animals at each age (Table 2 ). The differences in cortisol levels between age groups were variable with only the $1-\mathrm{d}$ versus $14-\mathrm{d}$ time 0 and $1-\mathrm{d}$ versus $7-\mathrm{d}$ time 30 differences reaching significance (Table 2). There were no significant changes in cortisol concentration from 0 to 60 $\mathrm{min}$ in any of the age groups. Serum cortisol levels were not correlated with serum GH concentration of any age.

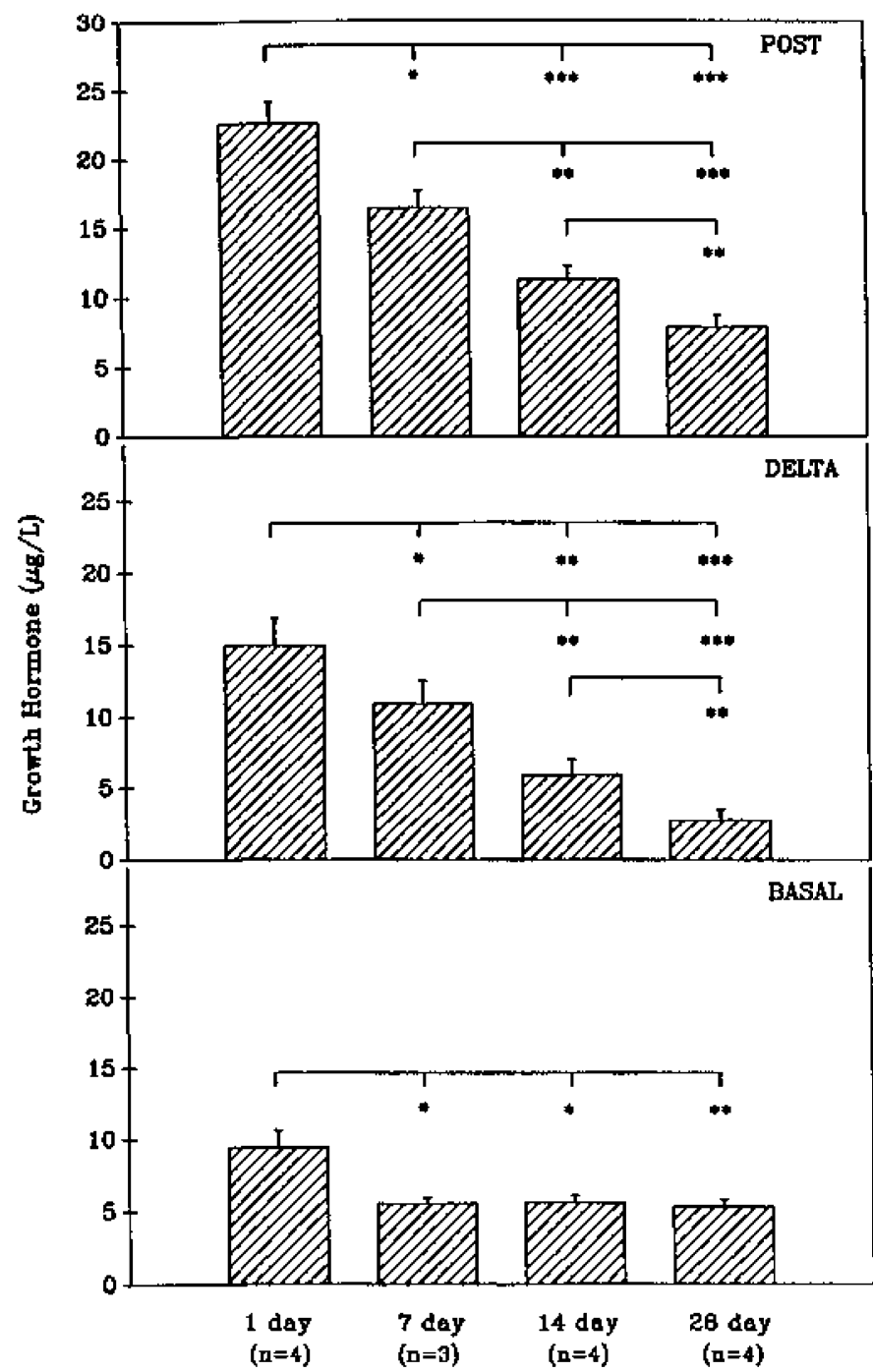

Fig. 1. Comparison of mean post-GHRH, mean $\delta$, and mean basal GH in response to $10 \mu \mathrm{g} / \mathrm{kg}$ of GHRH given i.v. to the same animals at the ages noted. One animal was studied only at 1,14 , and $28 \mathrm{~d}$. Statistical significance is indicated as a comparison of the group at the left end of a horizonlal line to all groups noted toward the right end of the line. Significant levels are indicated by the asterisks: ${ }^{*} p<0.05 ;{ }^{* *} p<0.0 \mathrm{I}$; $* * * 0<0.001$.

Table 1. Serum $G H$ response to $G H R H$ in rhesus monkeys (mean $\pm S E M)$

\begin{tabular}{rccccc}
\hline $\begin{array}{c}\text { Age } \\
(\mathrm{d})\end{array}$ & $\begin{array}{c}\text { Peak GH } \\
(\mu \mathrm{g} / \mathrm{L})\end{array}$ & $\begin{array}{c}\delta \text {-peak } \\
\mathrm{GH}(\mu \mathrm{g} / \mathrm{L})\end{array}$ & $\begin{array}{c}\text { Time } 0 \mathrm{GH} \\
(\mu \mathrm{g} / \mathrm{L})\end{array}$ & AUC* & $\hat{\delta}$-AUC $\mathrm{AUC}^{*}$ \\
\hline 1 & $30.2 \pm 3.5 \pm \$$ & $22.7 \pm 4.2 \|$ & $7.5 \pm 1.2$ & $1949 \pm 1661^{* * *}$ & $1271 \pm 256$ \\
7 & $19.7 \pm 3.6$ & $14.2 \pm 4.5$ & $5.5 \pm 1.0$ & $1409 \pm 228$ & $914 \pm 309$ \\
14 & $14.3 \pm 2.4 \$$ & $8.9 \pm 2.6$ & $5.4 \pm 0.4$ & $978 \pm 1861$ & $493 \pm 209$ \\
28 & $10.8 \pm 2.6 \S$ & $5.6 \pm 2.0 \|$ & $5.2 \pm 0.8$ & $679 \pm 143^{* *}$ & $214 \pm 95$ \\
\hline
\end{tabular}

* Area under curve after GHRH.

$\dagger$ Area after GHRH with baseline subtraction.

Levels of significance less than 0.05 between age groups are indicated by identical superscripts: $\ddagger 0.038 ; \S 0.013 ; \| 0.049 ; 10.026 ; * 0.005$.

\section{DISCUSSION}

The etiology of the elevation in serum GH during early neonatal development is unclear. Possible mechanisms include changes in hypothalamic GHRH or SRIH secretion, changes in pituitary sensitivity to GHRH or SRIH, maturation of negative feedback regulation by $\mathrm{GH}$ and somatomedins, and changes in intracellular mechanisms of storage and release. 